\title{
Dome-shaped maculopathy in the setting of Straatsma syndrome
}

\author{
Shrutakirty Parida, ${ }^{1}$ Srikanta Kumar Padhy, ${ }^{1}$ Debasmita Majhi, ${ }^{2}$ Anup Kelgaonkar (1) ${ }^{1}$
}

${ }^{1}$ Vitreo-retina and uveitis, LV Prasad Eye Institute, MTC campus, Bhubaneswar, India ${ }^{2}$ Paediatric and neuroophthalmology, LV Prasad Eye Institute, MTC campus, Bhubaneswar, Odisha, India

\section{Correspondence to} Dr Anup Kelgaonkar; anupnk2008@gmail.com

Accepted 13 July 2021

\section{DESCRIPTION}

A 35-year-old woman presented with acute-onset painless diminution of vision for both distance and near in her left eye for 1 month. She is a known case of hypothyroidism controlled on oral thyroxine. The best-corrected visual acuity (BCVA) at presentation was 20/20 (spherical equivalent of $-0.5 \mathrm{D}$ ) in right eye (OD) and 20/50 p (spherical equivalent of $-7 \mathrm{D})$ in left eye(OS), respectively. Examination of the anterior segment under the slit lamp was unremarkable. Dilated fundus examination of the left eye revealed yellowish-white retinal myelinated nerve fibres (RMNF) surrounding the disc, extending along all the four major vascular arcades-classified to be a type 2 RMNF variant, shallow posterior staphyloma at posterior pole with background fundus tessellation (figure 1A). Fundus examination of OD was essentially unremarkable. Swept-source optical coherence tomography (OCT) vertical scan passing through the fovea in OS demonstrated dome-shaped inward protrusion of

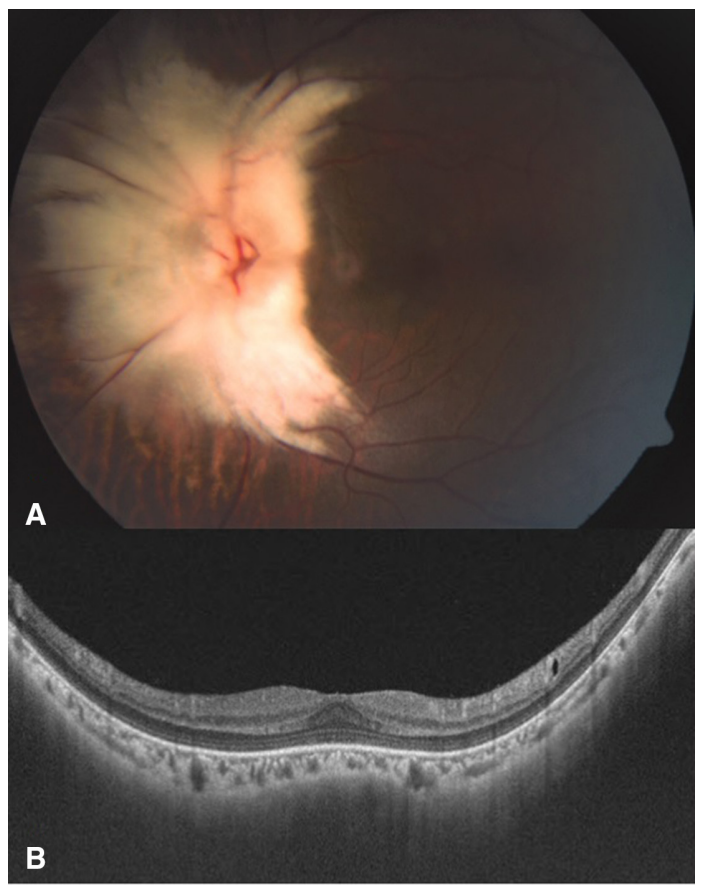

Figure 1 (A) Colour fundus image of the left eye showing myelinated nerve fibre layer involving disc and all four major arcades. The tessellated appearance of retina is seen. (B) Optical coherence tomography vertical scan of the left eye showing inwards bowing of scleral and choroid at the centre of the scan, while shallow posterior staphyloma configuration of the parafoveal retina is seen. macula inside the posterior staphyloma without an associated subretinal fluid in any of the radial scans (figure 1B). A diagnosis of Straatsma syndrome (a triad of RMNF, ipsilateral myopia and amblyopia) along with coexistent dome-shaped maculopathy (DSM) was made. Refractive error correction with contact lenses was advised to the patient and counselled regarding anisometropic amblyopia.

RMNF have been reported in around 1\% of the general population. ${ }^{12}$ Embryologically, the normal process of myelination of the visual pathway usually commences at the lateral geniculate body at around 20 weeks of gestational age, which proceeds centrifugally, finally terminating at the lamina cribrosa shortly after birth. The various phases of myelination reported in the literature include an immature phase, promyelination phase and the phase of myelination, being controlled by the myosin light-chain kinase (MLCK)/myosin 2 gene located in the Schwann cells. Several theories describing the pathophysiology of RMNF have been hypothesised, one relates RMNF to the failure of the lamina cribrosa in acting as an efficient barrier for detaining the anterograde optic nerve myelination, while the others attribute to the presence of heterotopic oligodendrocytes-like cells. ${ }^{34}$ Straatsma in the year 1979 described a specific syndrome comprising of a triad of amblyopia, high myopia and RMNF that

\section{Patient's perspective}

I am happy that my disease could be diagnosed so as to avail of immediate further consult and treatment. My family members and I have been apprised about my condition, its natural course and possible complications. The need for regular follow-up and self-awareness of visual loss has been explained to me in a language that I can easily understand.

\section{Learning points}

- Dome-shaped maculopathy (DSM) can lead to acute-onset vision loss in a patient with Straatsma syndrome.

- DSM in the setting of Straatsma syndrome is rare, may be an underreported/diagnosed entity that can be unmasked using high-definition optical coherence tomography.

- Visual prognosis in such patients are generally poor owing to pre-existing amblyopia with superadded maculopathy. 
are either isolated or associated with retinal vascular, craniocephalic and hamartoneoplastic disorders. ${ }^{5}$ The various poor prognostic factors consist of age at diagnosis, BCVA at presentation, type of fixation, the extent of myelination, degree of myopia and anisometropia. The amblyopia can be secondary to high myopiainduced retinal defocus (anisometropic) or RMNF-related direct interference of vision. ${ }^{5}$ DSM is an inward protrusion of the macula visualised on OCT initially documented in myopic eyes with posterior staphyloma, though later reported in eyes without staphyloma, emmetropia and hyperopia also. DSM is known to have a spectrum of presentations ranging from no symptoms, metamorphopsia, vision loss, pigment epithelial changes, retinoschisis to choroidal neovascularisation in advanced scenarios. ${ }^{6}$ The onset or progression of DSM in our case could be the cause of the recent unexplained drop in vision in the left eye. The vision deterioration in cases of DSM is known to occur due to reduced retinal sensitivity owing to a change in curvature of the retina. ${ }^{7}$ DSM in the setting of Straatsma syndrome is rare, may be an unreported entity to the best of our knowledge.

Contributors SKP and AK: conception of the idea, manuscript preparation, reviewing the manuscript and review of the literature. SP: data collection and manuscript writing. DM: manuscript reviewing and review of the literature.
Funding This study was funded by Hyderabad Eye Research Foundation (LVPEIbcr-2021-244355-2021).

Competing interests None declared.

Patient consent for publication Obtained.

Provenance and peer review Not commissioned; externally peer reviewed.

\section{ORCID iD}

Anup Kelgaonkar http://orcid.org/0000-0002-3983-4200

\section{REFERENCES}

1 Virchow R. Zur pathologischen Anatomie Der Netzhaut und des Sehnerven. Archiv $f$ pathol Anat 1856;10:170-93.

2 Straatsma BR, Foos RY, Heckenlively JR, et al. Myelinated retinal nerve fibers.. Am J Ophthalmol 1981;91:25-38.

3 Tarabishy AB, Alexandrou TJ, Traboulsi El. Syndrome of myelinated retinal nerve fibers, myopia, and amblyopia: a review. Surv Ophthalmol 2007;52:588-96.

4 FitzGibbon T, Nestorovski Z. Morphological consequences of myelination in the human retina. Exp Eye Res 1997;65:809-19.

5 Straatsma BR, Heckenlively JR, Foos RY, et al. Myelinated retinal nerve fibers associated with ipsilateral myopia, amblyopia, and strabismus. Am J Ophthalmol 1979;88:506-10.

6 Jain M, Gopal L, Padhi TR. Dome-shaped maculopathy: a review. Eye 2021. doi:10.1038/s41433-021-01518-w. [Epub ahead of print: 19 Apr 2021].

7 Pilotto E, Guidolin F, Parravano M, et al. Morphofunctional evaluation in DOMESHAPED macula: a microperimetry and optical coherence tomography study. Retina 2018;38:922-30.

Copyright 2021 BMJ Publishing Group. All rights reserved. For permission to reuse any of this content visit

https://www.bmj.com/company/products-services/rights-and-licensing/permissions/

BMJ Case Report Fellows may re-use this article for personal use and teaching without any further permission.

Become a Fellow of BMJ Case Reports today and you can:

- Submit as many cases as you like

- Enjoy fast sympathetic peer review and rapid publication of accepted articles

- Access all the published articles

Re-use any of the published material for personal use and teaching without further permission

Customer Service

If you have any further queries about your subscription, please contact our customer services team on +44 (0) 2071111105 or via email at support@bmj.com.

Visit casereports.bmj.com for more articles like this and to become a Fellow 